\title{
PEMBERITAAN DALAM MEDIA MASSA TELEVISI TERKAIT PEMILIHAN PRESIDEN 2014
}

\author{
Rendy H. Abraham \\ Mahasiswa Program Studi Magister Ilmu Komunikasi FISIP UNDIP Angkatan VI \\ Email:kk_rendo@yahoo.co.id
}

\begin{abstract}
Television is the most influential mass media is important today to portray a person or public figure to the public. Television today is just a tool for personal gain, regardless of the actual roles and functions to the public. With the theory of the political economy of the media as well as to consider ethics in the mass media, through this article tries to analyze the Content Content Coverage in Mass Media Television Related to the Presidential Election of 2014. The mass media only as an instrument for the ruling class to control the contents of the news content for personal gain. The mass media are considered not to provide impartial news and in accordance with the facts, so that people who should get the news and understanding of the actual figure of the presidential candidates can not be obtained. The mass media should look at what is needed community real and must be concerned with the interests of society as a means of gain accurate information and have a good understanding and correct knowledge will be a political democracy in the country, so that the role and function of the media as an agent of a conduit of information and knowledge in educating people can run well.
\end{abstract}

Keywords :the content, the mass mediatelevision, 2014 presidentialelection

\section{PENDAHULUAN}

Di era teknologi komunikasi dan informasi seperti sekarang ini, media massa sangat berperan untuk mendukung jalannya perputaran informasi kepada masyarakat informasi. Media massa sendiri berperan langsung untuk menyampaikan informasi ataupun berita kepada audiens. Seperti telah kita kenal, media massa terdiri dari media massa cetak dan elektronik. Media elektronik contohnya televisi dan radio. Sedangkan media cetak contohnya seperti surat kabar, majalah, tabloid, dan lain-lain.

Informasi yang diangkat oleh media massa sangat beragam. Media mengangkat berbagai hal dan permasalahan dalam kehidupan manusia, seperti permasalahan sosial, budaya, ekonomi, politik, gender, dan masih banyak lainnya yang menyangkut aspek kehidupan manusia. Pada dasarnya, media seharusnya merupakan cermin dan refleksi dari kondisi sosial budaya masyarakat. Harus diakui, sulit bagi sebuah media massa untuk bersikap seobjektif mungkin. Setiap wartawan maupun medianya selalu memiliki latar belakang dan berbagai faktor lainnya yang mempengaruhi cara berpikir, bertindak, dan memilih informasi untuk dilaporkan dan ditulis.

Media massa secara subjektif memproduksi nilai-nilai, ideologi, maupun pengetahuan. Dalam pemberitaannya dapa $t$ memunculkan suatu keberpihakan. Hal ini tentunya dipengaruhi oleh baik kepentingan media tersebut, rutinitasnya dan juga faktorfaktor eksternal, seperti: sumber berita, 
sumber ekonominya, hubungannya dengan pemerintah (independensi), dan lain-lain.

Sementara itu media massa, seperti disebutkan oleh Ansolabehere,dkk (1993: 139) dianggap sebagai perwakilan (agent) atas 'kepentingan' masyarakat. Media merupakan sumber informasi, pengetahuan, dan solusi atas permasalahan sosial yang dihadapi masyarakat. Media massa berperan dalam menentukan perkembangan pemikiran masyarakat. Melalui pembentukan opini publik misalnya, media memungkinkan khalayak untuk terus mengingat (learning) apa yang terjadi di sekitar mereka.

Berita harus memenuhi beberapa unsur yang nantinya akan membuat suatu berita tersebut layak untuk dipublish. Berita harus cepat dan cermat, dalam bahasa jurnalistiknya harus akurat selain akurat berita harus berimbang tidak boleh memihak. Berita harus objektif, Karena berita memiliki power untuk menciptakan opini public, jadi sesuatu yang ditulis oleh media harus memenuhi unsurunsur diatas agar tidak ada pihak yang dirugikan (Kusumaningrat, 2006:47)

Persoalannya, media massa tidak dapat menyampaikan suatu fakta secara utuh. Agar dapat memberikan informasi yang benar dan cepat terhadap masyarakat maka media atau pers dituntut untuk dapat bisa menambah pengetahuan pembacanya dengan menyajikan informasi atau berita yang berdasarkan fakta dari suatu peristiwa.

Sebagai pilar keempat demokrasi setelah eksekutif, legislatif, dan yudikatif di Indonesia, seharusnya media massa berada dalam sikap netral dan berimbang, khususnya di pemilihan presiden (Pilpres) 2014 ini. Dalam peristiwa yang terjadi akhir ini menyangkut pemilihan presiden 2014 oktober lalu sejumlah media massa televisi menampilkan pemberitaan yang tidak berimbang dan tidak sesuai dengan fakta yang ada, media massa lebih menyudutkan dan memihak terhadap kandidat tertentu dan memberikan pemberitaan yang terlalu berlebihan untuk seorang kandidat presiden, sesuai dengan pernyataan "Presiden Susilo Bambang Yudhoyono (SBY) mengkritisi pemberitaan media massa saat ini terkait pemilu yang disebutnya tidak berimbang dan tendensius. Bahkan Presiden secara eksplisit menyebut dua stasiun televisi nasional, Metro TV dan TV One, sebagai contoh ketidakberimbangan itu.Presiden berharap agar pers dan media massa bisa melakukan pemberitaan yang akurat dan konstruktif. Menurut dia, hal itu memang mudah untuk diucapkan, tetapi sangat sulit dilakukan para pemilik media."Saya harus gunakan kalimat terang.Sungguh pun agar pers di samping faktual, juga fair dan berimbang. Ini juga susah. Hakikatnya, saya ingatkan pada insan pers dan media massa, media massa milik publik dan untuk kepentingan publik, bukan hanya pemilik modal," kata Presiden.(http://riauone.com/news/detail/1721 /sby-pilpres-2014-pers-kita-terbelahpemberitaan-media-massa-terkait-pemilutidak-berimbang.html)

Hal serupa juga dikatakan oleh pengamat media menyebutkan penetapan jokowi sebagai calon presiden tidak lepas dari peran media massa selama ini, ia mengatakan "Media memiliki andil besar menjadikan Jokowi sebagai calon Presiden. Melalui berbagai berita, media telah menjadikan Jokowi sebagai sosok yang populer," kata Iswandi, Senin (24/3/2014).Iswandi menjelaskan, seharusnya media tidak boleh larut dalam suasana euforia Jokowi.Semakin populer Jokowi seharusnya media semakin bersikap kritis.Sikap kritis media ini diperlukan untuk meningkatkan kualitas media dalam sebuah sistem demokrasi.Iswandi yang juga penulis buku 
"Rezim Media" ini mengungkapkan kekecewaannya pada media yang tidak mampu bersikap kritis pada Jokowi.Dalam sistem demokrasi seperti saat ini, media memiliki fungsi memberikan pendidikan politik pada publik.Kalau ingin publik terdidik dan cerdas menggunakan hak politiknya, mereka harus diberi informasi yang seimbang," lanjutnya. Menurut Iswandi sikap kritis media terhadap Jokowi bisa dilakukan dengan cara menyampaikan berbagai kelemahan Jokowi. (http://www.tribunnews.com/pemilu-

2014/2014/03/24/media-harus-berimbangsoal-jokowi). Media dinilai tidak dapat memberikan pemberitaan yang berimbang dan sesuai dengan fakta, sehingga masyarakat yang seharusnya memperoleh berita dan pemahaman mengenai sosok calon presiden yang sesungguhnya tidak bisa didapat.

Selain itu sejumlah media massa dinilai telah gagal mengemban tugas utama mencerdaskan bangsa. Malahan media tertentu menjerumuskan, menyesatkan, dan membodohi masyarakat.Kepentingan politik yang dipaksakan pemilik media membuat awak pers tidak berkutik untuk mengikuti arahan, kehendak, dan misi pemodal.Itulah yang terjadi pada media tertentu selama perjalanan sebelum, selama, dan setelah Pemilihan Presiden 2014.Ada media yang terang-terangan melawan arus hasil hitung cepat dari sejumlah lembaga yang kredibel dan malahan menampilkan hasil hitungan lembaga yang dinilai terkooptasi sehingga metodologi dan hasilnya sangat diragukan.

Beberapa kasus mengenai isi dan pemberitaan media massa tersebut media seharusnya melihat apa yang dibutuhkan masayarakat sesungguhnya dan harus mementingkan kepentingan masyarakat sebagai suatu sarana mendapat informasi yang akurat dan memperoleh pemahaman yang baik dan benar tentang pengetahuan akan demokrasi politik di negara Indonesia, sehingga peran dan fungsi media sebagai agen pemberi nformasi dan pengetahuan dalam mendidik masyarakat dapat berjalan dengan baik.

Teori Tanggung Jawab Sosial Media (The four theories of press) dikategorikan sebagai teori normatif, karena teori-teori ini mendeskripsikan norma, sesuatu yang seharusnya, atau kondisi ideal yang terjadi. Teori normatif memberikan gagasan mengenai bagaimana media harus dikelola dan bertujuan untuk melayani kebutuhan masyarakat dan berkontribusi terhadap sistem politik secara luas dimana teori pers itu berlaku (Littlejohn, 2009: 574).

Teori tanggung jawab sosial melibatkan pandangan tentang kepemilikan media sebagai bentuk kepercayaan dan pengawasan publik, alih-alih sebagai waralaba swasta yang tidak terbatas. William Hocking (1974: 169) menyatakan: hak pers untuk bebas tidak terpisahkan dari hak rakyat untuk memiliki pers yang bebas. Akan tetapi, kepentingan publik melampaui titik tersebut; saat ini merupakan hak untuk memiliki pers yang layak, dan dari dua hak tersebut, ia menambahkan: hak bagi publik sekarang untuk mengambil preseden. Hal ini merupakan dasar bagi tuntutan untuk tanggung jawab.

\section{PERUMUSAN MASALAH}

Berdasarkan penjelasan latar belakang diatas jelas bahwa media massa televisi saat ini tidak lagi mementingkan kepentingan publik melainkan kepentingan politik para pemilik media, dimana pemberitaan tersebut terkait pilpres 2014 sangat tidak berimbang dengan memihak pada salah calon tertentu dan menyudutkan calon pasangan lain. 
Sebagai peran dan fungsinya seharusnya media bisa memberikan informasi yang baik dan benar mengenai sosok calon pasangan presiden kepada masyarakat bukan memihak pada calon tertentu yang mengakibatkan pemberitaan tidak sesuai dengan fakta yang terjadi.Selain itu, media juga harus jujur dan terbuka dalam penyampaian informasi baik peristiwa maupun latar belakang calon presiden yang benar sehingga masayarakat bisa lebih memahami sosok calon dan dapat memilih dengan benar bukan dengan adanya pemberitaan yang terlalu berlebihan dan menonjolkan pasangan tertentu dengan menutupi kelemahan yang dimiliki. Berdasarkan fakta tersebut "Bagaimanakah institusi media dapat memberikan isi dan pemberitaan yang wajar dan berimbang dalam memberikan pengetahuan bagi masyarakat"

\section{PEMBAHASAN}

Pembahasan mengenai Isi Konten Pemberitaan Dalam Media Massa Televisi Terkait Pemilihan Presiden 2014 dapat menggunakan teori ekonomi politik media yang merupakan pendekatan kritik sosial yang berfokus pada hubungan antara struktur ekonomi dan dinamika industri media dan konten ideologi media (McQuail, 2011: 105). Yang artinya bahwa, kekuasaan mengenai isi media massa di kontrol oleh pemilik media demi mendapat keuntungan dengan mengabaikan tanggung jawab media kepada masyarakat dalam memberikan informasi yang seharusnya.

Media massa adalah ruang publik (public sphere). Dalam buku The Structural Transformation of The Public Sphere, Habermas menyatakan secara umum bahwa "public sphere" adalah ruang untuk membangun diskursus publik demi terbentuknya masyarakat kritis yang mampu mengontrol kebijakan negara. Ruang publik harus bersifat bebas, terbuka, transparan dan tidak ada intervensi pemerintah, kaum pemilik modal, kelompok kepentingan, maupun pemasang iklan didalamnya (McQuail, 2005: 181).Media seharusnya adil dalam memberitakan suatu berita terkait dengan Pemilihan Presiden 2014 yang dinilai kurang terbuka dalam menyampaikan informasi politik, sehingga masyarakat tidak mendapatkan haknya dalam menerima informasi yang benar.

Media membawa sejumlah tugas penting dan pokok dalam masyarakat kontemporer dan menjadi kepentingan umum agar tugas-tugas tersebut dijalankan dengan baik.Hal ini juga menyiratkan bahwa kita harus memiliki sistem media yang beroperasi menurut prinsip pemerintahan yang juga mengatur masyarakat, terutama yang berkaitan dengan keadilan, kebenaran, demokrasi, dan gagasan yang mengatur nilai sosial dan budaya yang diinginkan.Secara jelas menurut kepentingan publik bahwa media tidak menyebabkan masalah sosial maupun serangan ekstrim (McQuail, 2011: 180).

Pemberitaan dalam media massa televisi terkait pemilihan Presiden 2014 televisi sebagai media massa menampilkan pemberitaan yang tidak berimbang dan tidak sesuai dengan fakta yang ada, media massa lebih menyudutkan dan memihak terhadap kandidat tertentu dan memberikan pemberitaan yang terlalu berlebihan untuk seorang kandidat presiden. Secara jelas bahwa media menimbulkan permasalahan dalam sosial masyarakat, media seharusnya memberikan pendidikan serta pemahaman politik pada masyarakat yang berimbang, bukan hanya untuk kepentingan pemilik modal. 
Dalam masyarakat yang demokratis, masyarakatlah yang memerintah, media yang demokratis harus mendengarkan suara masyarakat dan bukan hanya suara para pakar. Menurut Theodore Peterson (dalam Siebert, Peterson, \& Schramm, 1996: 74), perbedaan esensial media dalam konsep atau teori tanggung jawab sosial adalah, "media must assume obligation of social responsibilty; and if they do not, someone must see they do". Media dalam teori ini dipandang memiliki kewajiban kepada masyarakat, media harus bebas nilai namun mampu mengukur dirinya sendiri, pemberitaan harus akurat, jujur, dan obyektif, dan mematuhi kode etik.

\section{Teori Tanggung Jawab Sosial (Social Responsibility Theory)}

Teori Tanggung Jawab Sosial Media (The four theories of press) dikategorikan sebagai teori normatif, karena teori-teori ini mendeskripsikan norma, sesuatu yang seharusnya, atau kondisi ideal yang terjadi. Teori normatif memberikan gagasan mengenai bagaimana media harus dikelola dan bertujuan untuk melayani kebutuhan masyarakat dan berkontribusi terhadap sistem politik secara luas dimana teori pers itu berlaku (Littlejohn, 2009: 574).

Teori tanggung jawab sosial berasal dari Commission on Freedom of the Press (Hutchins, 1974) sebagai reaksi atas interpretasi dan pelaksanaan model libertarian yang ada. Komisi tersebut merumuskan beberapa persyaratan pers sebagai berikut:
a. Memberitakan peristiwa-peristiwa sehari- hari dengan benar, lengkap dan berpekerti dalam konteks yang mengandung makna.
b. Memberikan pelayanan sebagai forum untuk saling tukar komentar dan kritik.
c. Memproyeksikan gambaran yang mewakili semua lapisan masyarakat

d. Bertanggung jawab atas penyajian disertai penjelasan mengenai tujuan dan nilai-nilai masyarakat.

e. Mengabdi sistem politik yang menyajikan informasi, diskusi dan perdebatan mengenai permasalahan-permasalahan umum.

f. Memberikan penerangan kepada masyarakat sehingga turut berpartisipasi untuk pemerintahan sendiri.

g. Mengabdi sistem ekonomi terutama mengenai para penjual dan pembeli barang dan jasa melalui periklanan.

h. Menyajikan hiburan.

Teori tanggung jawab sosial melibatkan pandangan tentang kepemilikan media sebagai bentuk kepercayaan dan pengawasan publik, alih-alih sebagai waralaba swasta yang tidak terbatas. William Hocking (1974: 169) menyatakan: hak pers untuk bebas tidak terpisahkan dari hak rakyat untuk memiliki pers yang bebas. Akan tetapi, kepentingan publik melampaui titik tersebut; saat ini merupakan hak untuk memiliki pers yang layak, dan dari dua hak tersebut, ia menambahkan: hak bagi publik sekarang untuk mengambil preseden. Hal ini merupakan dasar bagi tuntutan untuk tanggung jawab.Media seharusnya lebih mengutamakan kepentingan publik untuk memberikan informasi dan pengetahuan yang benar, bukan sebaliknya menciptakan realitas palsu, tidak sesuai dengan kebenaran dan hanya berfokus pada kepentingan pribadi.

\section{Perlunya Etika Komunikasi: Etika dalam Menyampaikan Informasi Kini Telah Pudar}

Etika tidak hanya dibutuhkan dalam kehidupan bersosialisasi terhadap lingkungan kita.Etika dibutuhkan di berbagai aspek kehidupan, termasuk dalam dunia komunikasi. Hal ini pun telah dibentuk dalam 
berbagai kode etik profesi yang berkaitan dengan komunikasi di Indonesia. Fungsinya tak lain adalah sebagai pedoman dalam memberikan informasi kepada masyarakat, khususnya oleh media, untuk menjaga agar hak publik untuk mendapatkan informasi yang benar dapat terpenuhi. Namun sangat disayangkan, media yang ada sekarang ini justru lebih mengarahkan usahanya sebagai komoditas di dalam dunia bisnis.Akibatnya, etika kerap kali terbengkalai dan terkalahkan oleh pertarungan kepentingan dalam hal politik, ekonomi, atau budaya.

Informasi hanya dianggap sebagai alat untuk meraih keuntungan sebesar mungkin, bahkan media terkadang mengorbankan profesionalismenya demi menampilkan sesuatu yang lebih sensasional atau spektakuler agar dapat meningkatkan nilai jualnya. Akibatnya, kerja wartawan yang berada di dalam media tersebut pun kini seakan hanya terbatas pada mempublikasikan kehidupan selebritis dan orang-orang penting yang laku dipasaran. Hal ini menunjukkan betapa kejamnya dunia bisnis terhadap kelangsungan hidup komunikasi melalui media yang sesungguhnya. Bahkan banyak pimpinan media datang dari dunia perusahaan bukan dari dunia jurnalisme, dan harus diakui bahwa mereka tidak peka terhadap tuntutan informasi yang sesungguhnya.

Pudarnya etika dalam tubuh media menyebabkan fenomena yang tampak seperti logika simulasi, dimana orang tidak akan dapat mencapai kebenaran karena antara realitas, representasi, hiperrealitas, atau tipuan tidak dapat dibedakan lagi (Haryatmoko, 2007: 22).Yang dimaksud dengan etika di dalam pembahasan ini tidak hanya terbatas pada apa yang disampaikan kepada publik. Jelas bahwa kebenaran dan keakuratan isi berita merupakan hal utama yang harus diperhatikan dalam proses penyampaian informasi tersebut. Namun perlu diingat bahwa bahasa yang dipergunakan, fakta-fakta kejadian-kejadian yang difokuskan dalam pemberitaan juga perlu dipertimbangkan kembali sebelum digunakan untuk membentuk berita tersebut. Frekuensi dan sudut pandang pemberitaan pun perlu diperhatikan agar tidak menimbulkan permasalahan baru. Hal ini bukan dilakukan bukan hanya demi pandangan masyarakat tentang media itu sendiri, melainkan juga untuk menjaga narasumber itu sendiri.

Contoh kasus dari pemberitaan media yang dapat kita ambil tentang bagaimana akibatnya jika etika dalam bisnis media tidak dipedulikan adalah pemberitaan yang dilakukan oleh MetroTV dan beberapa stasiun televisi lain terkait Pilpres 2014, dalam pemberitaan tersebut MetroTV secara terus menerus selalu menampilkan konten yang menayangkan profil dan kelebihan Jokowi dengan menutupi segala kelemahan dan kekurangan sebagai seorang calon dan ada yang menyudutkan calon pasangan lain. Hal tersebut jelas bahwa selain konten media yang tidak benar dan berimbang juga dipengaruhi oleh pemilik media tersebut yang lebih mementingkan kepentingan politik dari pada kepentingan publik yang perlu mengetahui informasi yang benar sebagaimana mestinya fungsi media dalam mneyampaikan infromasi kepada publik.Selain itu ada juga media yang memberikan informasi hasil perhitungan cepat pilpres dengan membingungkan masyarakat sehingga hasil yang sangat diragukan. Dalam peristiwa Pilpres lalu yang menggembirakan karena meningkatkan antusiasme masyarakat datang ke tempat pemungutan suara di satu sisi, namun di bagian lain, telah melahirkan media yang tidak adil, berat sebelah, dan mendekati penipuan informasi. Banyak informasi yang disajikan media massa tidak objektif, menyimpang, dan terdistorsi. 
Terkait dengan penjelasan diatas jelas bahwa perkembangan ini sebagai bentuk tanggung jawab warga yang menuntut informasi mencerdaskan terhadap eksistensi media massa dan sangat tidak profesional media massa yang mengelabui masyarakat dan melawan kodratnya sebagai pencerdas. Media yang tidak mencerdaskan apalagi malah menyesatkan, bukan hanya mengingkari kodrat eksistensinya, tetapi juga tengah memasang jerat yang akan menelikung diri sendiri ditinggalkan audiens/masyarakat. Hal juga tentunya akan merugikan media sendiri Jika sampai ditinggalkan pembaca, pendengar, atau pemirsa, itu berarti sebuah upaya bunuh diri bagi media massa. Tidak ada gunanya modal besar tanpa audiens.Pelanpelan masyarakat menilai media tertentu biasa mendistorsi isi berita, membengkokkan nilainilai.Hanya tinggal menghitung hari media ini untuk mati. Maka, jika masih ingin dihargai, dihormati, dan dipercaya, media massa yang selama pilpres telah merasa membodohi masyarakat dengan informasi-informasi menyimpangnya, segeralah bertobat dan kembali ke jalan benar. Ini berarti dia kembali bersikap profesional, integral, dan objektif.

\section{PENUTUP}

Peran media massa dalam komunikasi massa adalah sangat besar dan saling keterkaitan dan tak dapat dipisahkan. Media massa dewasa ini sangat berperan besar dalam menentukan opini ataupun pemikiran masyarakat baik itu sosial, budaya dan politik, jadi sudah selayaknya jika media massa memberitakan sesuatu yang sekiranya bermanfaat dan bersifat mendidik. Fungsi komunikasi massa memang banyak, seyogyanya jika apa yang disampaikan memenuhi salah satu dari fungsi-fungsi tersebut. Alangkah lebih baik media menyajikan sesuatu yang lebih cerdas dan berguna bagi masyarakat.Bukan sebaliknya, memberikan isi konten yang tidak faktual dan tidak berimbang, yang dapat merugikan masyarakat sendiri sebagai khalayak media.

Media massa seharusnya bisa ikut meramaikan pesta demokrasi dengan menyampaikan informasi tentang politik atau pemilu dengan baik dan mendidik masyarakat. Penyampaian informasi atau berita dengan fakta yang obyektifdan berimbang selain itu media juga seharusnya tidak memihak pada salah satu capres, apalagi memihak dengan cara menyampaikan rekayasa berita yang menyudutkan atau membunuh karakter sehingga tanggung jawab terhadap sosial masyarakat dan prinsip etika komunikasi dalam penyampaian informasi melalui media massa tidak terabaikan.

\section{DAFTAR PUSTAKA}

DR. A. Sonny Keraf.(2006). Etika Bisnis. Yogyakarta : Kanisius.

Johanes, Richard L. (1996). Ethics in Human Communication (Third Edition), Etika Komunikasi. Bandung: PT. Remaja Rosdakarya.

Littlejohn, Stephen W. and Karen Foss.(2009). Encyclopedia of Communication Theories USA: SAGE Publication

McQuail, Dennis. (2000). McQuail's Mass Communication Theory, 4th Edition. New Delhi: SAGE publications Ltd.

McQuail, Denis. (2012)Teori Komunikasi Massa.Jakarta : Salemba Humanika

Turner, Lynn H and Richard West.(2008). Pengantar Teori Komunikasi: Analisis dan Aplikasi New York: McGraw-Hill

Siebert, Fred. S; Theodore Peterson, and Wilbur Schramm. (1963). Four Theories of The Press: The Authotarian, Libertarian, Social Responsibilty, and Soviet Communist 
JURNAL INTERAKSI, Vol 5 No. 2, Juli 2016 : 201-208

Concept of What the Press Should Be

and Do. Chicago: University of Illinois Press.

Internet :

http://riauone.com/news/detail/1721/sbypilpres-2014-pers-kita-terbelahpemberitaan-media-massa-terkaitpemilu-tidak-berimbang.html.

http://www.tribunnews.com/pemilu-

2014/2014/03/24/media-harus-berimbangsoal-jokowi 